\title{
Land use/cover and landscape pattern changes in Manas River Basin based on remote sensing
}

\author{
Xiaolong $\mathrm{Li}^{1,2}$, Xinlin $\mathrm{He}^{1,2^{*}}$, Guang Yang ${ }^{1,2}$, Hongguang $\mathrm{Liu}^{1,2}$, Aihua Long ${ }^{3}$, \\ Fulong Chen ${ }^{1,2}$, Bing $\operatorname{Liu}^{1,2}$, Xinchen $\mathrm{Gu}^{1,2}$ \\ (1. College of Water \& Architectural Engineering, Shihezi University, Shihezi 832000, Xinjiang, China; \\ 2. Xinjiang Production \& Construction Group Key Laboratory of Modern Water-Saving Irrigation, Shihezi 832000, Xinjiang, China; \\ 3. Department of Water Resources, China Institute of Water Resources and Hydropower Research, Beijing 100038, China)
}

\begin{abstract}
Large-scale water and soil development in inland river basins in arid areas has made changes in landscape composition and structure, threatening the ecological balance. In order to study the trend of land use/cover and landscape pattern change and its relationship with water resources utilization in Manas River Basin, the land-use data of five periods in 1976, 1990, 2000, 2010 and 2015 were analyzed. The results showed that: (1) During 1976-2015, farmland and construction land continuously increased, forest land and grassland continuously decreased, the water area initially reduced and then increased, the area of saline-alkali land initially increased and then reduced, the overall trend of unused land and the sandy area was decreasing and the area of different time periods is floating. The areas of land-use types either increased or decreased. This indicates that the landscape pattern of the basin changes dramatically, and human activities are the main reasons for this phenomenon; (2) The oasis area increased from $3480.2 \mathrm{~km}^{2}$ in 1976 to $7982.0 \mathrm{~km}^{2}$ in 2015 , with an obvious increasing trend. The oasis area clearly increased during 1976-1990, the growth rate was $40.6 \%$, the growth rate of the oasis area was $129.4 \%$. In the last 40 years, the degree of desertification fluctuated and decreased. The increase of the oasis area directly leads to the increase of water resources utilization and aggravates the degree of water resources shortage; (3) The pattern of land-use types showed a non-equilibrium trend. In the region with increasing landscape heterogeneity, the overall landscape pattern was increasingly controlled by the majority of patches. The intensive land management model and drip irrigation under mulch have improved the utilization efficiency of water resources and saved water resources from engineering renovation and irrigation management.
\end{abstract}

Keywords: arid area, Manas River Basin, land use/cover change, landscape pattern, remote sensing, driving force DOI: $10.25165 /$ j.ijabe.20201305.4783

Citation: Li X L, He X L, Yang G, Liu H G, Long A H, Chen F L, et al. Land use/cover and landscape pattern changes in Manas River Basin based on remote sensing. Int J Agric \& Biol Eng, 2020; 13(5): 141-152.

\section{Introduction}

Land degradation is a severe environmental problem on a regional and global scale and is often aggravated by intensive land use and climate change ${ }^{[1,2]}$. Agricultural intensification and subsequent land abandonment and reforestation significantly affect the hydrological behavior and connectivity patterns of hydrological systems. Thus, information on the spatial distribution of land use/cover is essential for monitoring the runoff response to interpret catchment hydrology ${ }^{[3]}$. The geometric characteristics of landscape pattern are often reflected by the method of direct analysis of landscape pattern index or model analysis ${ }^{[4-6]}$. Due to

\section{Received date: 2019-11-17 Accepted date: 2020-07-31}

Biographies: Xiaolong $\mathbf{L i}, \mathrm{PhD}$, research interest: agricultural water-soil engineering, Email: 370441537@qq.com; Guang Yang, Professor, research interest: hydrology and water resources, Email: mikeyork@163.com; Hongguang Liu, Professor, research interest: agricultural water-soil engineering, Email: 123868194@qq.com; Aihua Long, Professor, research interest: hydrology and water resources, Email: 673505306@qq.com; Fulong Chen, Professor, research interest: hydrology and water resources, Email: 24619302@qq.com; Bing Liu, Professor, research interest: hydrology and water resources, Email: 515441180@qq.com; Xinchen Gu, Master, research interest: hydrology and water resources, Email: 969322029@qq.com.

*Corresponding author: Xinlin He, $\mathrm{PhD}$, Professor, research interest: hydrology and water resources. College of Water \& Architectural Engineering, Shihezi University, Shihezi 832000, Xinjiang, China. Tel: +86-13150401816; Email: hexinlin2002@163.com drought and less rain in arid areas, the large-scale water and soil development process changed the spatial and temporal distribution pattern of water resources in Manas River Basin. In terms of the influence process of human activity on landscape pattern change, the direct influence is that during the process of large-scale soil and water development, the time and space distribution of water resources are changed, and some original vegetation degradation $\operatorname{occurs}^{[7,8]}$. Some original vegetation becomes artificial vegetation and artificial settlements, and indirectly represents the decline or rise of the groundwater level caused by overexploitation of groundwater and heavy irrigation using surface water, which change the characteristics of soil and the growth state of vegetation in the region, so that the basin landscape tends to undergo desertification and salinization ${ }^{[9]}$. On the one hand, the underlying surface condition of the northwest arid area depends on water resources, which is relatively simple compared to the landscape structure in the moist area, and the ecological environment is relatively fragile. On the other hand, many areas in Xinjiang are under local and corps division management, which makes the change of Land Use/Cover Change (LUCC) and landscape pattern change in the basin more complex. Because of the high degree of human intervention, the landscape composition and structure changes are frequent and lead to the very obvious fragmentation of the landscape. The artificial reclamation of oases and the overexploitation and utilization of water resources 
will affect the stability of arid areas to a certain extent, and will also limit agricultural production and socially sustainable development in the region.

There are many research cases on LUCC and landscape pattern change in the basin. Landsat Thematic Mapper (TM) data of 1990 and 2010 were acquired by the Global Land Cover Facility and Earth Explorer sites and used to quantify the changes in the Hawalbagh block over a period of 20 years from 1990-2010. The results indicated that, during the last two decades, vegetation and built-up land had increased by $3.51 \%\left(9.39 \mathrm{~km}^{2}\right)$ and $3.55 \%$ $\left(9.48 \mathrm{~km}^{2}\right)$, respectively, while agriculture, barren land and water body decreased by $1.52 \%\left(4.06 \mathrm{~km}^{2}\right), 5.46 \%\left(14.59 \mathrm{~km}^{2}\right)$ and $0.08 \%\left(0.22 \mathrm{~km}^{2}\right)$, respectively ${ }^{[10]}$. A supervised classification was applied to four Landsat images collected over time (1984, 1999, 2005, and 2009) that provided recent and historical LULC conditions for the western Nile delta. Approximately 28\%, 14\%, and $9 \%$ of barren land was changed to agricultural land in the periods 1984-1999, 1999-2005, and 2005-2009, respectively. In addition to these LULC changes, evidence of land degradation processes was observed, which were mainly due to human activities, such as the formation of quarries, free water bodies and Sabkhas (a specific type of land cover found on drylands and salt-affected soils $)^{[10]}$. Pixel-based supervised image classification was used to map land-use/cover classes. People's perceptions and ecological time-lines were used to explain the driving forces linked to the changes. A rapid reduction in woodland cover (97\%) and grassland cover (88\%) took place between 1972 and $2007^{[11]}$. The opposite trend was observed between the 1980s and 2000s; forest regeneration was greater than deforestation at the landscapes with $10 \%$ and $50 \%$ of forest cover, and as a consequence, forest cover increased. By contrast, the percentage of forest cover in the landscape with $30 \%$ of forest cover was drastically reduced between the 1980s and 2000s. LULCC deviated from a random trajectory, were not constant through time in two study landscapes and were not constant across space in given time ${ }^{[12]}$. The previous land-use study data were for short periods and unevenly distributed, and the studies were not performed regularly. There has been little LUCC research based on comprehensive basin-scale data over long time periods. In addition, studies on the interaction between LUCC and landscape pattern are relatively weak.

As the fourth largest irrigated area in Xinjiang, the Manas River Basin, due to the rapid growth of farmland, has experienced a sharp change in ecological water use, and Manas Lake has gradually atrophied and vanished in this process. Dozens of rare desert species in the downstream desert have degenerated or become extinct. Taking the Manas River Basin of the north slope of the Tianshan Mountains in Xinjiang as an example, this paper uses the remote-sensing image classification and comparison method to carry out land-use spatio-temporal change monitoring and GIS technology and the landscape ecology method, according to the land-use data for the five periods of 1976, 1990, 2000, 2010 and 2015. The data superposition and landscape transfer matrix reveal the spatio-temporal transformation of landscape types, allow calculation of landscape indexes to analyze the fragmentation of land use/cover types and explore the general rules of the impact of land-use change on landscape pattern. This can reveal the stability of the landscape and the degree of human interference to a certain extent. The results are of great significance in determining the internal mechanism of land-use change in the basin, promoting the rational development of water and soil resources in the basin and promoting regional sustainable development and regional ecological security.

\section{Materials and methods}

\subsection{Study area survey}

The Manas River Basin is located at the northern foot of the Tianshan Mountains of Xinjiang and the southern edge of the Junggar Basin, as shown in Figure 1. It is located at the center of the economic belt on the north slope of the Tianshan Mountains. The administrative region includes Shihezi, Shawan and Manas counties, and the farmland of the Eighth and Sixth Agricultural Division of Xinjiang Production and Construction Corps in the two counties $^{[13]}$. Its geographical location is $43^{\circ} 27^{\prime}-45^{\circ} 21^{\prime} \mathrm{N}, 85^{\circ} 01^{\prime}$ $-86^{\circ} 32^{\prime} \mathrm{E}$ with a total area about $3.40 \times 10^{4} \mathrm{~km}^{2}$ from the southeast to the northwest. The highest altitude is $5242 \mathrm{~m}$ and the lowest is $256 \mathrm{~m}$, and the terrain slopes are 1/30-1/100. From south to north, it can be divided into three geomorphic types: mountainous area, piedmont plain and desert (ratio about 2.08:1:1.07) ${ }^{[14]}$. The Taxi, Manas, Ningjia, Jingou and Bayinggou Rivers in the basin originate from the Yilian Habierga Mountains in the northern foot of the Tianshan Mountains and flow into the Junggar Basin from south to north ${ }^{[15]}$. The Manas River has a total length of $324 \mathrm{~km}$, a catchment area of $5156 \mathrm{~km}^{2}$ in the mountainous area and an average annual runoff of $11.79 \times 10^{8} \mathrm{~m}^{3}$. It is the inland river with the largest water volume and the longest flow in the Junggar Basin and eventually enters Manas Lake in the northwest of the Junggar $\operatorname{Basin}^{[16]}$. There is a national hydrological station, Kensiwate Hydrological Station, in the upper reaches of the Manas River with a controlled area of $4637 \mathrm{~km}^{2[17]}$.

The Manas River Basin is an inland arid area with hot and dry summer, cold and windy winter, with an annual average temperature of $4.7^{\circ} \mathrm{C}-5.7^{\circ} \mathrm{C}$, annual average precipitation of 100 $200 \mathrm{~mm}$, annual average evaporation of $1500-2100 \mathrm{~mm}$ and a typical temperate continental arid climate. The main landscape types are grassland, unused land and farmland, accounting for about $90 \%$ of the whole basin area. The landscape pattern is very variable. Over the years of development, the basin water resources have been beneficial to the expansion of farmland and the changes in landscape patterns. In recent years, due to changes in the natural environment, the continuous growth of the population, the development of the economy and inappropriate utilization of water and soil resources in some areas, the land use/cover and landscape patterns of the basin have changed in time and space. A series of problems have occurred, such as lakes drying up, grasslands degrading, land desertification, soil salinization and biodiversity reduction.

\subsection{Data processing}

The time interval of the Manas River Basin Land Use Database is 1976-2015, which is divided into five periods: 1976, 1990, 2000, 2010 and 2015. For the study and selection of data sources for 1976 Landsat MSS, and 1990, 2000, 2010 TM and 2015 ETM remote-sensing images, the resolution is $30 \mathrm{~m} \times 30 \mathrm{~m}$, using image processing software ERDAS IMAGE and 1:10 million topographic maps were used to calibrate and splice the above images, generating the images for the above five years. On the basis of comprehensive considerations of spectral information and texture features of remote-sensing data, combined with characteristics of this arid region, the land resource classification system was merged into eight types: farmland, forest land, grassland, water, construction land, unused land, sand land and saline-alkali land. Using ARCGIS10.1, according to the five-phase remote-sensing image of the study area, the remote-sensing data were translated 
and digitized according to the above classification system, and the topological relation established to generate land-use graphic data and corresponding attribute data. Remote sensing satellite data and selection conditions are shown in Table 1.

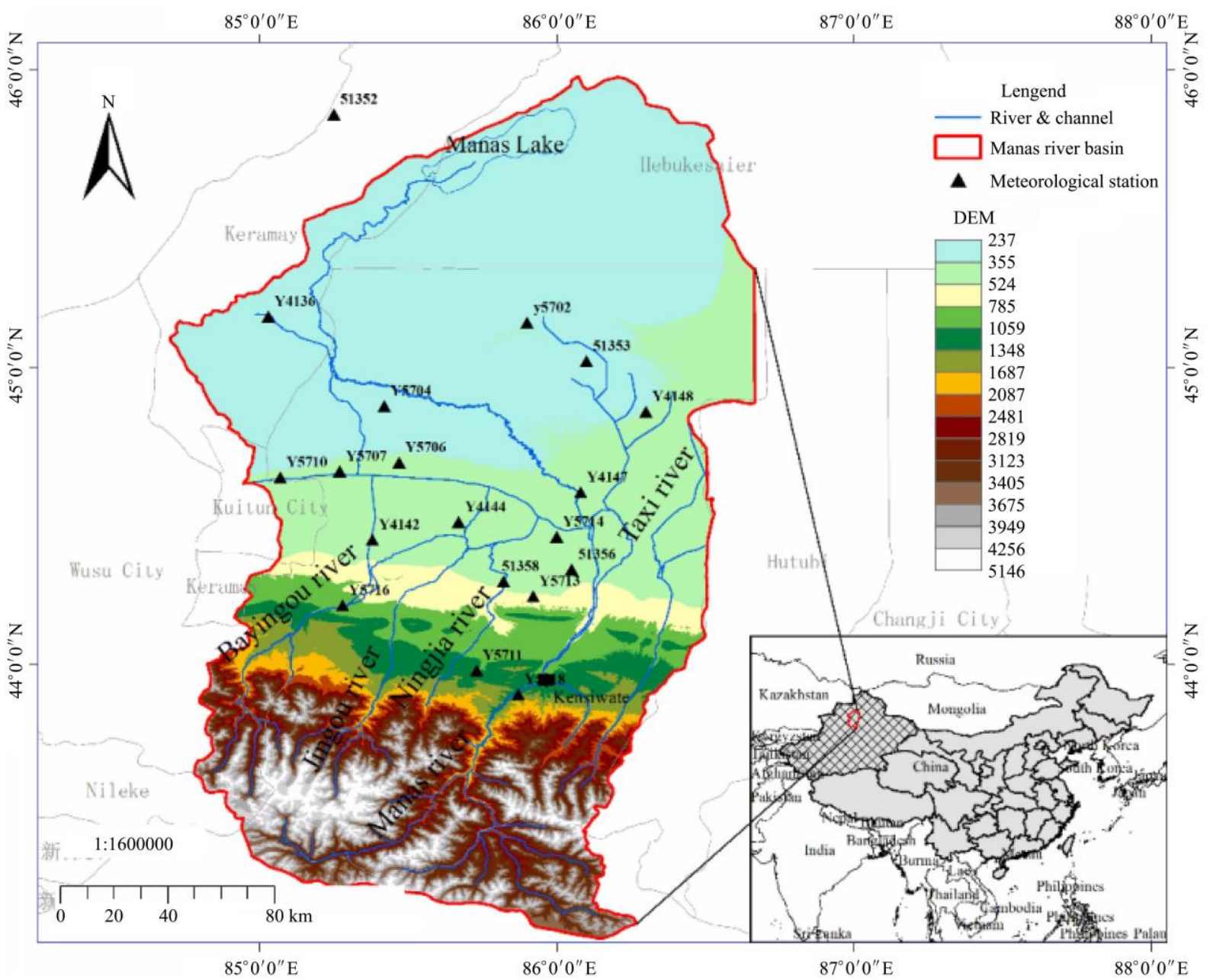

Figure 1 Geographical location and river distribution of the Manas River Basin

Table 1 Remote sensing satellite data and selection conditions

\begin{tabular}{ccccc}
\hline Satellite name & $\begin{array}{c}\text { Satellite } \\
\text { sensor }\end{array}$ & $\begin{array}{c}\text { Cloudiness over } \\
/ \%\end{array}$ & $\begin{array}{c}\text { Resolution } \\
/ \mathrm{m}\end{array}$ & $\begin{array}{c}\text { Date of satellite } \\
\text { shooting }\end{array}$ \\
\hline LANDSAT2 & MSS & 10 & 60 & $1976-09-26$ \\
& & 0.01 & & $1990-06-03$ \\
\hline \multirow{2}{*}{ LANDSAT5 } & TM & 7.6 & 30 & $2000-08-08$ \\
& & 6.45 & & $2010-08-11$ \\
\hline LANDSAT7 & ETM+ & 0 & 30 & $2015-08-17$ \\
\hline
\end{tabular}

The confusion matrix method is used to evaluate the accuracy of remote sensing interpretation. According to the watershed geographic information in 2015, 150 random points were extracted to verify the confusion matrix. These random units include farmland, forest land, grassland, water, construction land, unused land, sand land, saline-alkali land; according to the field survey results and high-resolution images of Google Earth, the land types in the study area were verified. The results showed that the classification accuracy of farmland, grassland, forest land, water, construction land, unused land, sand land and saline alkali land were $81.2 \%, 83.6 \%, 82.5 \%, 84.7 \%, 80.4 \%, 81.7 \%, 83.6 \%$ and $82.1 \%$, respectively. Kappa coefficient was 0.86 , which met the needs of macroscopic land use and watershed landscape pattern analysis.

In the remote sensing interpretation of land use types in Manas River Basin, based on the comprehensive consideration of spectral information and texture characteristics of remote sensing image data, combined with the characteristics of the arid area, the land use classification system was combined. The secondary land types of land use in the basin were merged into 8 types, including farmland, forest land, grassland, water, construction land, unused land, sand land, saline-alkali land. Some linear features, such as some roads, rural roads, ditches and shelterbelts, cannot be classified separately due to technical treatment, so they are classified into the above land categories and will not be listed separately. Rules for the merging land use classification system are shown in Table 2.

Table 2 Rules for merging land use classification system during 1976-2015 in the study area

\begin{tabular}{|c|c|c|}
\hline $\begin{array}{l}\text { Serial } \\
\text { number }\end{array}$ & $\begin{array}{l}\text { First level } \\
\text { classification }\end{array}$ & Secondary classification \\
\hline 1 & Farmland & Dry land, irrigated land \\
\hline 2 & Forest land & $\begin{array}{l}\text { Arbor garden, arbor greenbelt, shrubs, } \\
\text { evergreen coniferous forest, sparse shrub } \\
\text { forest, broadleaved deciduous forest, } \\
\text { broadleaved deciduous shrub }\end{array}$ \\
\hline 3 & Grassland & $\begin{array}{l}\text { Grassland, marshy grassland sparse grassland, } \\
\text { herbaceous marshes, herbaceous greenland }\end{array}$ \\
\hline 4 & Water & $\begin{array}{l}\text { River, lake, canal, reservoir/pond, } \\
\text { glaciers/perpetual snow }\end{array}$ \\
\hline 5 & Construction land & Residential area, traffic land, industrial land \\
\hline 6 & Unused land & Bare soil, bare rock \\
\hline 7 & Sand land & Desert/sand land \\
\hline 8 & Saline-alkali land & Saline alkali land \\
\hline
\end{tabular}




\subsection{Representation method of land-use change}

The process and trend of land-use change can be characterized by quantitative elements or values (for example, total change, net change, state, direction and trend). The mathematical expressions of the indexes follow:

$$
\begin{gathered}
P_{s}=\frac{N_{c}}{T_{c}}=\frac{\Delta U_{\text {in }}-\Delta U_{\text {out }}}{\Delta U_{\text {in }}+\Delta U_{\text {out }}},\left(\Delta U_{\text {in }}+\Delta U_{\text {out }} \neq 0 \quad \& \quad-1 \leq P_{s} \leq 1\right) \\
P_{t}=\frac{S_{a}}{S_{s}}=\frac{\sum_{i=1}^{n}\left|\Delta U_{\text {in }-i}-\Delta U_{\text {out }-i}\right|}{\sum_{i=1}^{n}\left|\Delta U_{\text {in }-i}+\Delta U_{\text {out }-i}\right|},\left(S_{s} \neq 0 \quad \& \quad 0 \leq P_{t} \leq 1\right)
\end{gathered}
$$

where, $N_{c}, T_{c}$ and $P_{s}$ are net area change index, total change index and trend and state index of A of a single land type, respectively; $S_{a}$, $S_{s}$ and $P_{t}$ are the comprehensive net change index, comprehensive total change index and comprehensive trend and state index of all land types, respectively; $U_{a}$ and $U_{b}$ are the area of a land-use type $\mathrm{A}$ in the early and late stages, respectively; $\Delta U_{\text {out }}$ is the sum of other types of type A areas in the study period; $\Delta U_{\text {in }}$ is the sum of the other types of A in the same period; $U_{a i}$ and $U_{b i}$ are the area of $i$-th types of land types in the early and late stages of study, respectively; $\Delta U_{\text {out }-i}$ is the sum of the areas that the $i$-th land types that changed into other types during the study period; $\Delta U_{i n-i}$ was the sum of the areas that the other types changed into from the $i$-th type; and $n$ is the number of land-use types.

\subsection{Representation model of landscape pattern change}

Landscape pattern is not only the embodiment of landscape heterogeneity but is also the result of different ecological processes at different scales ${ }^{[18,19]}$. The landscape pattern index is a quantitative index of highly concentrated landscape pattern information, which is usually used to reflect the structural composition and spatial allocation of the regional landscape. The landscape pattern and dynamic trend can be described in detail by choosing an appropriate landscape index, according to the ecological significance expressed by the research objective, analysis scale and index. The landscape diversity, dominance, fragmentation, evenness and landscape separation indexes were selected to analyze landscape structure and spatial variation, and the spatio-temporal variation of landscape pattern is discussed. The mathematical expressions of landscape indexes are as follows:

$$
\begin{gathered}
H=-\sum_{k=1}^{m} P_{k} \ln P_{k} \\
D=H_{\max }+\sum_{k=1}^{m} P_{k} \ln P_{k} \\
F_{N}=\left(N_{p}-1\right) / N_{c} \\
E=\frac{H}{H_{\max }} \times 100 \% \\
I_{i}=\frac{D_{i}}{S_{i}}=\frac{1 / 2 \sqrt{n / A}}{A_{i} / A}
\end{gathered}
$$

where, $H$ is the diversity index of landscape type. This index can reflect the heterogeneity of landscape, especially sensitive to the unbalanced distribution of patch types in the landscape. $D$ is the dominance index of landscape type. It is inversely proportional to the diversity index. For different landscapes with the same number of landscape types, the larger the diversity index, the smaller the dominance degree. $F_{N}$ is the fragmentation index of landscape type. The fragmentation index represents the fragmentation degree of landscape, reflects the complexity of landscape spatial structure, and reflects the degree of human disturbance to the landscape to a certain extent. $E$ is the evenness index of a landscape type, as the dominance index, describes the extent to which the landscape is controlled by a few major landscape types. These two indices can be verified by each other. $I_{i}$ is the separation index of landscape type $i$, which refers to the degree of separation of individual distribution of different patches in a landscape type. $\quad P_{k}$ is the proportion of landscape type $k$ area to the total area, $\mathrm{m}$ is the number of landscape types, $N_{p}$ indicates the total number of patches in the landscape, $N_{c}$ is the ratio of the total area to the smallest patch area, $H_{\max }$ is the largest diversity index of the landscape type, $D_{i}$ is the distance index of landscape type $i, S_{i}$ is the area index of landscape type $i, A$ is the landscape total area, $A_{i}$ is the total area of landscape type $i$ and $n$ is the number of patches for each type.

\section{Results and discussion}

\subsection{LUCC in different periods}

The LUCC is considered to be the most typical process for displaying human activities at the landscape scale. It not only objectively records the spatial pattern of human changes on the surface of the earth but also reproduces the spatio-temporal dynamic change process of the earth's surface landscape. The study of LUCC in the Manas River Basin can quantitatively reveal the LUCC process, spatial and temporal distribution and the trend and rate of LUCC in recent decades, which can help in analyzing the response relationship of LUCC to human activities.

The spatio-temporal evolution of LUCC in the five periods over 40 years in the study area were analyzed by remote sensing and GIS technology, and the area transfer matrix data of various types were obtained. Through the land-use change characterization method, the net change index, total change index, trend and state index of single land-use type areas, the comprehensive net change index, the comprehensive total change index, and the comprehensive trend and state index of all land types of land-use type change in four different periods were calculated.

The extent of LUCC varied in different periods and types. The mainland use/cover types were grassland, sandy land, saline-alkali soil, unused land and farmland. According to the classification results of 1976, the grassland area was $13109.67 \mathrm{~km}^{2}$, the sandy land area was $6598.16 \mathrm{~km}^{2}$ and the saline-alkali land area was $4315.71 \mathrm{~km}^{2}$, corresponding to $38.50 \%, 19.38 \%$ and $12.68 \%$ of the total study area, respectively. By 1990, the land use/cover types had changed greatly, with the increase of farmland and the decrease of grassland most obvious. Farmland increased from $3030.86 \mathrm{~km}^{2}$ in 1976 to $4394.06 \mathrm{~km}^{2}$, an increase of $1363.2 \mathrm{~km}^{2}$, accounting for $12.91 \%$ of the study area. The proportion of grassland decreased from $38.50 \%$ in 1976 to $35.35 \%$. The other land use/cover types slightly expanded with construction land and saline-alkali land increasing by 0.14 and $0.20 \%$, respectively. In 2000 , the farmland area had further increased by $208.01 \mathrm{~km}^{2}$, compared to 1990; however, the expansion rate had slowed, and the area of saline-alkali, sandy, unused and construction land increased by $1.08 \%, 0.38 \%, 0.10 \%$ and $0.02 \%$, respectively. The grassland area continued to decrease, from $35.35 \%$ in 1990 to $33.40 \%$ in 2000. At the same time, the forest land and water area were reduced by $0.05 \%$ and $0.02 \%$, compared to 1990 . In 2010 , the area of cultivated land increased to $5424.53 \mathrm{~km}^{2}$ from $4602.07 \mathrm{~km}^{2}$ in 2000 , an increase of $2.41 \%$ annually, and the rate of expansion was obvious. Meanwhile, the area of unused land, construction land and water area rose from $9.16 \%, 0.77 \%$ and $6.07 \%$, respectively, to $9.45 \%, 0.85 \%$ and $6.09 \%$. The proportion of grassland areas decreased year by year, from $33.40 \%$ in 2000 to $31.73 \%$ in 2010 , with an area of $567.40 \mathrm{~km}^{2}$. The area of forest land, saline-alkali land and sandy land decreased by $39.12 \mathrm{~km}^{2}$, 
$182.36 \mathrm{~km}^{2}$ and $164.83 \mathrm{~km}^{2}$, respectively. In 2015 , the farmland area continued to increase compared to 2010 , with an increase of $828.11 \mathrm{~km}^{2}$. The water area and construction land area increased by $85.92 \mathrm{~km}^{2}$ and $54.94 \mathrm{~km}^{2}$, respectively. The grassland area continued to decrease, from $10803.83 \mathrm{~km}^{2}$ in 2010 to $10064.16 \mathrm{~km}^{2}$ in 2015 , a reduction of $739.67 \mathrm{~km}^{2}$. The forest land, unused land, sandy land and saline-alkali land were reduced by $65.43 \mathrm{~km}^{2}, 82.91$ $\mathrm{km}^{2}, 43.27 \mathrm{~km}^{2}$ and $37.68 \mathrm{~km}^{2}$ compared to 2010 (Figure 3).
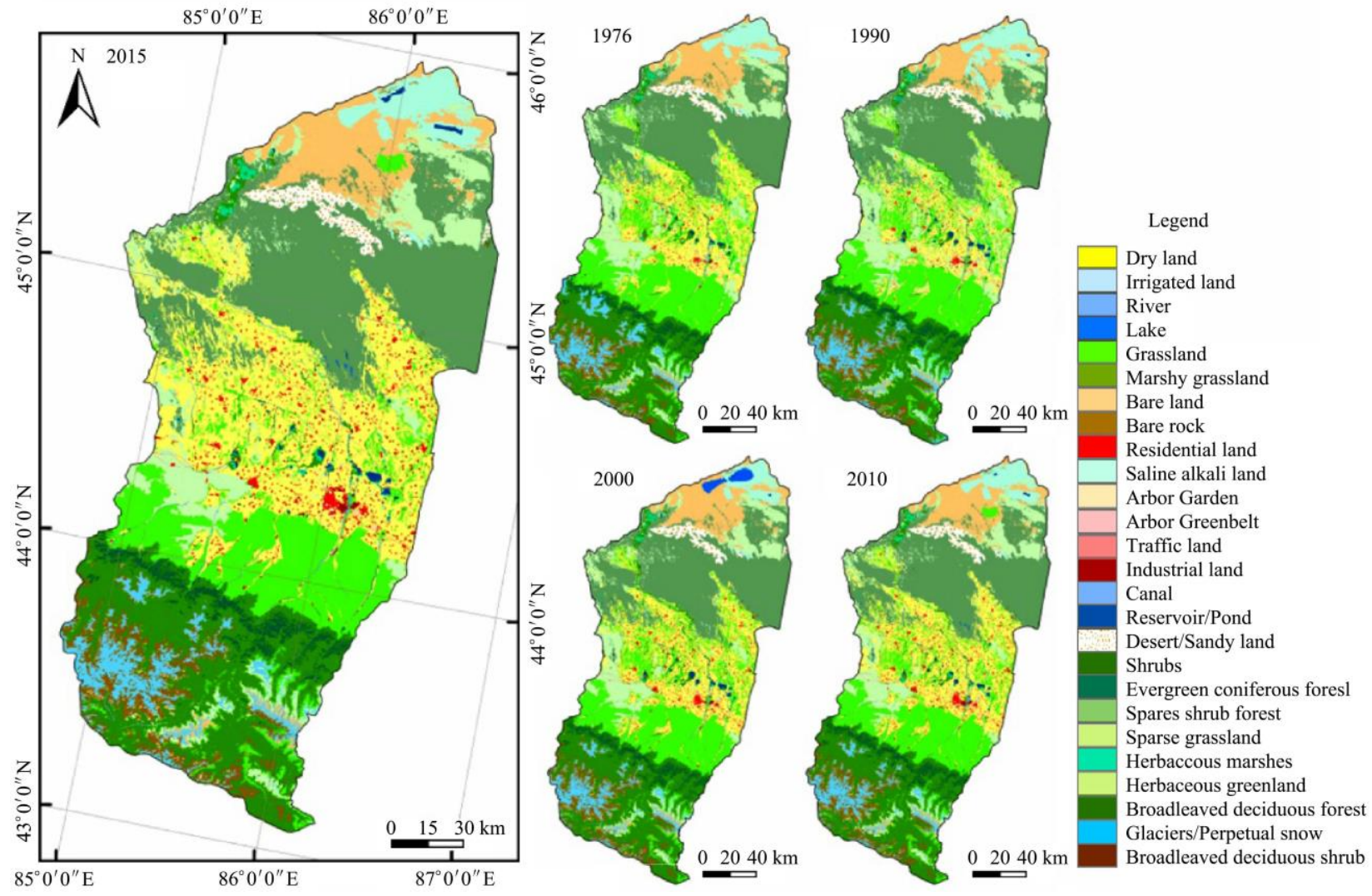

Figure 2 Land-use cover changes for 1976-2015 in the study area

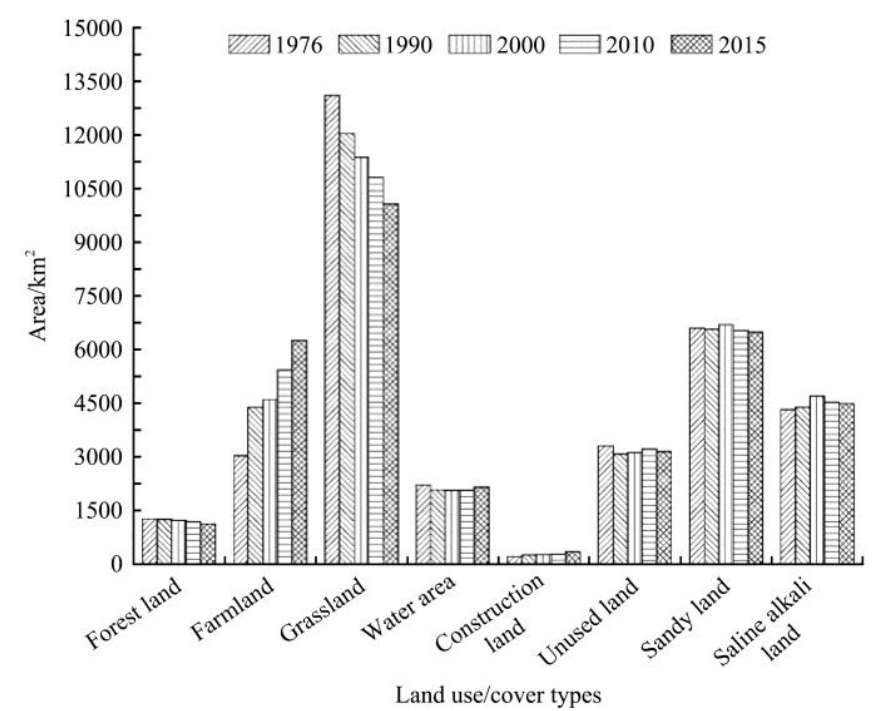

Figure 3 Changes in land use/cover types in different periods of the study area

The land use/cover type area fluctuated more obviously in the whole research area, and the area floating in different time periods is different, and the land use/cover type areas increased and decreased. The farmland and construction land increased during 1976-2015: farmland increasing by $3221.78 \mathrm{~km}^{2}$, with an annual dynamic degree of 2.66; and construction land increased by $135.11 \mathrm{~km}^{2}$, with an annual dynamic degree of 1.61 . The woodland and grassland continuously reduced from 1976-2015: forest land reduced by $128.31 \mathrm{~km}^{2}$, with an annual dynamic degree of -0.30 ; and grassland reduced by $3045.51 \mathrm{~km}^{2}$, with an annual dynamic degree of -0.58 . The water area initially declined and then increased: during 1976-2000, the area was reduced by $146.76 \mathrm{~km}^{2}$, with an annual dynamic degree of -0.27 ; and during 2000-2015, it increased by $91.8 \mathrm{~km}^{2}$, with an annual dynamic degree of 0.3 . The area of saline-alkali land initially increased and then reduced; during 1976-2000 it increased by $381.23 \mathrm{~km}^{2}$, with an annual dynamic degree of 0.35; and during 2000-2015 the area declined by $220.04 \mathrm{~km}^{2}$, with an annual dynamic degree of -0.31 . During 1976-2015, unused land and sandy land areas increased and decreased, with the overall trend being a decrease: in 1976 , the areas were $3312.90 \mathrm{~km}^{2}$ and $6598.16 \mathrm{~km}^{2}$, respectively; and, in 2015 , the corresponding areas were $3133.65 \mathrm{~km}^{2}$ and $6488.12 \mathrm{~km}^{2}$, representing reductions of $179.25 \mathrm{~km}^{2}$ and $110.04 \mathrm{~km}^{2}$, respectively.

The transfer matrix of land use/cover change comes from the quantitative description of system state and state transfer in system analysis. The row represents the land use type at $\mathrm{T} 1$ time point and the list represents the land use type at $\mathrm{T} 2$ time point. It can quantitatively show the transformation between different land-use types, and also reveal the transfer rate between different land-use types.

In 1976-1990, the land-use changes in the Manas River Basin were in an unbalanced state, with two-way conversions frequent the comprehensive net change index was $4.3 \%$, the total change index was $10.73 \%$ and the trend index was 0.4 , indicating that conversion of land-use types was mainly transferred in. The representation index of land-use type change showed that the net change index of farmland, construction land and saline-alkali land was $44.98 \%, 21.82 \%$ and $1.62 \%$, respectively, with trend index of 
$0.62,0.23$ and 0.18 , mainly in the way of transfer in. The LUCC transfer matrix of the Manas River Basin for 1976-1990 showed that the transfer-in areas of farmland and construction land were $1773.82 \mathrm{~km}^{2}, 122.52 \mathrm{~km}^{2}$ and $229.54 \mathrm{~km}^{2}$, respectively, with transfer rates of $58.53 \%, 58.52 \%$ and $5.32 \%$. The net change indexes of forestland, grassland, water, unused land and sandy land were $-0.55,-8.19,-6.35,-6.85$ and -0.45 , respectively, with trend indexes of $-0.03,-0.41,-0.21,-0.33$ and -0.10 , showing that these land-use types were mainly transferred out, and the corresponding transferred areas were $129.4 \mathrm{~km}^{2}, 1837.14 \mathrm{~km}^{2}$, $408.92 \mathrm{~km}^{2}, 457.58 \mathrm{~km}^{2}$ and $171.8 \mathrm{~km}^{2}$. From 1976-1990, the farmland area was greatly affected by the policy, and the farmland area expanded rapidly mainly from changes in grassland and unused land (Table 3).

Table 3 Transfer matrix of land use/cover changes in the Manas River Basin during 1976-1990 (km²)

\begin{tabular}{|c|c|c|c|c|c|c|c|c|c|}
\hline & Forest land & Grassland & Water area & Farmland & $\begin{array}{c}\text { Construction } \\
\text { land }\end{array}$ & Unused land & Sandy land & $\begin{array}{l}\text { Saline-alkali } \\
\text { land }\end{array}$ & $\begin{array}{c}\text { Area transferred in, } \\
1990\end{array}$ \\
\hline Forest land & 1092.48 & 60.8 & 23.09 & 19.25 & 1.94 & 11.58 & 4.25 & 1.58 & 122.49 \\
\hline Grassland & 96.02 & 9828.3 & 302.13 & 291.82 & 28.2 & 42.83 & 0.38 & 1.43 & 762.81 \\
\hline Water area & 4.08 & 143.71 & 1663.2 & 3.96 & 0.19 & 33.08 & 75.57 & 7.71 & 268.3 \\
\hline Farmland & 12.31 & 1573.09 & 2.58 & 4041.2 & 45.9 & 139.6 & 0 & 0.3 & 1773.82 \\
\hline Construction land & 1.36 & 20.85 & 0.14 & 94.17 & 104.96 & 5.07 & 0.9 & 0.03 & 122.52 \\
\hline Unused land & 7.93 & 36.82 & 80.95 & 0.95 & 0.56 & 2947.14 & 90.66 & 12.88 & 230.75 \\
\hline Sandy land & 4.95 & 0.25 & 0 & 0 & 0 & 0.8 & 6562.04 & 135.86 & 141.86 \\
\hline Saline-alkali land & 2.75 & 1.62 & 0.03 & 0.47 & 0.05 & 224.58 & 0.04 & 4156.11 & 229.54 \\
\hline Area transferred out, 1976 & 129.4 & 1837.14 & 408.92 & 410.62 & 76.84 & 457.58 & 171.8 & 159.79 & \\
\hline
\end{tabular}

During 1990-2000, the land-use changes in the Manas River Basin were slower than for 1976-1990, with a comprehensive net change index of $2.02 \%$, a total change index of $17.89 \%$ and a trend index of 0.11 , indicating that land-use types were mainly transferred in. The representation index of land-use type change showed that the net change index of farmland, construction land, unused land, sandy land and saline-alkali land was $4.73 \%, 2.92 \%$, $1.04 \%, 1.95 \%$ and $7.1 \%$, respectively, with trend indexes of 0.08 , $0.02,0.02,0.17$ and 0.31 . The LUCC transfer matrix for 1990-2000 showed that the transfer areas of farmland, construction land, unused land, sandy land and saline-alkali land were $1373.05 \mathrm{~km}^{2}, 183.66 \mathrm{~km}^{2}, 704.72 \mathrm{~km}^{2}, 449.88 \mathrm{~km}^{2}$ and $655.86 \mathrm{~km}^{2}$, respectively. The transfer of farmland was mainly from forestland and grassland. The net change index of forestland, grassland and water were $-1.35,-5.52$ and -0.30 , respectively, with trend index of $-0.02,-0.17$ and -0.01 . This shows that the land-use type was mainly transferred out, and these areas were $558.72 \mathrm{~km}^{2}$, $2310.26 \mathrm{~km}^{2}$ and $543.62 \mathrm{~km}^{2}$, respectively, with the rate of transfer out of $44.70 \%, 19.20 \%$ and $26.22 \%$. During 1990-2000, the reclamation increase rate was slow, limited by traditional irrigation methods, irrigation and drainage systems were poor, secondary soil salinization of farmland was common and farmland development was blocked (Table 4). Land-use change areas continued to expand along with Manas, Shihezi and Shawan and extended to the northern desert, forming an oasis belt in the middle of the basin.

Table 4 Transfer matrix of land use/cover changes in the Manas River Basin during 1990-2000 (km²)

\begin{tabular}{|c|c|c|c|c|c|c|c|c|c|}
\hline & Forest land & Grass land & Water area & $\begin{array}{l}\text { Farm } \\
\text { land }\end{array}$ & $\begin{array}{c}\text { Construction } \\
\text { land }\end{array}$ & Unused land & Sandy land & $\begin{array}{l}\text { Saline } \\
\text { alkali land }\end{array}$ & $\begin{array}{c}\text { Area transferred in, } \\
2000\end{array}$ \\
\hline Forest land & 674.61 & 381.36 & 11.88 & 93.43 & 2 & 24 & 16.46 & 12.74 & 541.87 \\
\hline Water area & 18.47 & 198.28 & 1523.32 & 24.41 & 1.09 & 295.23 & 0 & 0 & 537.48 \\
\hline Farmland & 103.4 & 932.5 & 23.72 & 3422.63 & 138.43 & 17.51 & 62.32 & 95.17 & 1373.05 \\
\hline Construction land & 4.86 & 29.86 & 1.45 & 143.92 & 96.77 & 0.6 & 1.36 & 1.61 & 183.66 \\
\hline Sandy land & 20.08 & 182.07 & 0.65 & 71.77 & 0.5 & 6.67 & 6369.38 & 168.14 & 449.88 \\
\hline Saline-alkali land & 19.49 & 269.79 & 0.59 & 197.48 & 4.63 & 22.05 & 141.83 & 4354.78 & 655.86 \\
\hline Area transferred out, 1990 & 558.72 & 2310.26 & 543.62 & 1165.04 & 176.21 & 672.56 & 321.88 & 344.38 & \\
\hline
\end{tabular}

During 2000-2010, the change of land use in the Manas River Basin was extremely unbalanced, with frequent one-way transfers the comprehensive net change index was $2.8 \%$, the total change index was $3.36 \%$ and the trend index was 0.83 , indicating that the land-use type was mainly transferred in. The net change indexes of water, farmland, construction land and unused land were $0.28 \%$, $17.87 \%, 10.30 \%$ and $3.15 \%$, respectively; with corresponding trend indexes of $0.20,0.90,0.85$ and 0.69 ; transfers in area of $17.54 \mathrm{~km}^{2}$, $869.10 \mathrm{~km}^{2}, 29.35 \mathrm{~km}^{2}$ and $120.20 \mathrm{~km}^{2}$; and transfer rates of $0.85 \%$, $16.02 \%, 10.14 \%$ and $3.74 \%$. During this period, the scope of land-use change continued to extend, mainly to the Gurbantungut Desert in the northern part of the basin, and the oasis of the flood plain area in the middle of the basin gradually became one piece, forming an oasis group. The forestland, grassland, sandy land and saline-alkali land were reduced and transferred into farmland. The Xinjiang Production and Construction Corps reclaimed a large amount of shrubland, sparse grassland and unused land near roads and arable land, leading to a continuous increase in farmland area. Analysis of land-use data for 2000-2010 showed that the net change index of woodland, grassland, sandy land and saline-alkali land was $-3.17 \%,-4.99 \%,-2.46 \%$ and $-3.88 \%$, respectively, and a trend index of $-0.64,-0.85,-0.72$ and -0.88 which indicated that the land-use type was mainly transferred out. The areas of transfer out were $50.09 \mathrm{~km}^{2}, 617.93 \mathrm{~km}^{2}, 196.91 \mathrm{~km}^{2}$ and $195.20 \mathrm{~km}^{2}$, respectively (Table 5). The reasons for the change of land use were large-scale soil and water development in the Manas River Basin, especially in the alluvial-proluvial plain area with shallow groundwater, convenient traffic and denser population - a large amount of unused land was reclaimed as farmland so that farmland and construction land increased rapidly. At the same time, the area of unused land and woodland decreased greatly. Compared with 1990-2000, unused land 
during 2000-2010 increased, mainly due to the abandonment of salinized farmland and degradation of forest land and grassland, and the decrease in surface water bodies accelerated the vegetation degradation.

Table 5 Transfer matrix of land use/cover changes in the Manas River Basin during 2000-2010 $\left(\mathrm{km}^{2}\right)$

\begin{tabular}{|c|c|c|c|c|c|c|c|c|c|}
\hline & Forest land & Grassland & Water area & Farmland & $\begin{array}{c}\text { Construction } \\
\text { land }\end{array}$ & Unused land & Sandy land & $\begin{array}{l}\text { Saline-alkali } \\
\text { land }\end{array}$ & $\begin{array}{c}\text { Area transferred in, } \\
2010\end{array}$ \\
\hline Forest land & 1144.13 & 7.31 & 0 & 1.69 & 0 & 0.01 & 0.86 & 1.10 & 10.97 \\
\hline Grassland & 4.35 & 10185.9 & 10.40 & 15.42 & 0.03 & 8.10 & 11.34 & 0.89 & 50.53 \\
\hline Water area & 1.67 & 9.68 & 2061.15 & 1.56 & 0 & 3.63 & 1.00 & 0 & 17.54 \\
\hline Farmland & 39.21 & 467.29 & 0.41 & 5377.89 & 2.28 & 10.13 & 174.772 & 175.01 & 869.10 \\
\hline Construction land & 1.72 & 3.61 & 0 & 16.48 & 287.36 & 0 & 0 & 7.54 & 29.35 \\
\hline Unused land & 0.48 & 113.61 & 0.85 & 1.97 & 0 & 3194.50 & 3.22 & 0.07 & 120.20 \\
\hline Sandy land & 1.93 & 15.79 & 0 & 3.77 & 0 & 0 & 6334.48 & 10.59 & 32.08 \\
\hline Saline-alkali land & 0.73 & 0.64 & 0 & 5.75 & 0 & 0 & 5.72 & 4319.45 & 12.84 \\
\hline Area transferred out, 2000 & 50.09 & 617.93 & 11.66 & 46.64 & 2.31 & 21.87 & 196.91 & 195.20 & \\
\hline
\end{tabular}

During 2010-2015, the change of land use in the Manas River Basin was in an unbalanced state - the comprehensive net change index was $2.85 \%$, the total change index was $7.54 \%$ and the trend index was 0.38 , indicating that the type of land use in this stage was mainly transferred in. The net change indexes of water, farmland and construction land were $4.15 \%, 15.27 \%$ and $18.97 \%$, respectively; with trend indexes of $0.59,0.5$ and 0.12 ; transfer in areas of $116.12 \mathrm{~km}^{2}, 1243.62 \mathrm{~km}^{2}$ and $255.24 \mathrm{~km}^{2}$; and transfer rates of $5.38 \%, 19.89 \%$ and $74.09 \%$. The reduced areas of forest land, grassland and unused land were mainly changed into farmland, and the area of farmland continued to increase. The main land-use types that transferred out were forestland, grassland, unused land, sandy land and saline-alkali land, with transfer-out areas of $397.34 \mathrm{~km}^{2}, 865.27 \mathrm{~km}^{2}, 254.13 \mathrm{~km}^{2}, 230.35 \mathrm{~km}^{2}$ and
$172.9 \mathrm{~km}^{2}$, respectively, and the rate of transfer out was $35.20 \%$, $13.84 \%, 8.11 \%, 3.55 \%$ and $2.66 \%$, respectively. The representation index of land-use type change showed that the net change indexes of forestland, grassland, unused land, sandy land and saline-alkali land were $-5.48 \%,-6.85 \%,-2.58 \%,-0.66 \%$ and $-0.84 \%$, respectively, and the main transfer-out types were forestland and grassland. The corresponding trend indexes were $-0.09,-0.75,-0.19,-0.1$ and -0.12 , indicating that the transferred out proportions of grassland and unused land were greater (Table 6). In the Manas River Basin, the drip irrigation technique was introduced in 1996 and, after 20 years of development and popularization, the oasis reclamation rate had greatly increased. The growth of farmland was closely related to the water-saving irrigation technology in the basin.

Table 6 Transfer matrix of land use/cover changes in the Manas River Basin during 2010-2015 (km²)

\begin{tabular}{|c|c|c|c|c|c|c|c|c|c|}
\hline & Forest land & Grassland & Water area & Farmland & $\begin{array}{l}\text { Construction } \\
\text { land }\end{array}$ & Unused land & Sandy land & $\begin{array}{l}\text { Saline-alkali } \\
\text { land }\end{array}$ & $\begin{array}{c}\text { Area transferred in, } \\
2015\end{array}$ \\
\hline Forest land & 731.40 & 2.67 & 0.22 & 5.93 & 0.04 & 100.35 & 222.40 & 0.30 & 331.91 \\
\hline Grassland & 0.36 & 9036.94 & 21.86 & 70.09 & 0.55 & 30.39 & 1.80 & 0.55 & 125.60 \\
\hline Water area & 4.32 & 24.67 & 2028.53 & 3.27 & 0.13 & 18.04 & 0.66 & 65.03 & 116.12 \\
\hline Farmland & 380.41 & 821.59 & 5.08 & 5536.65 & 22.43 & 9.25 & 3.14 & 1.72 & 1243.62 \\
\hline Construction land & 0.64 & 12.49 & 0.52 & 236.43 & 321.33 & 4.33 & 0.56 & 0.27 & 255.24 \\
\hline Sandy land & 0.01 & 0.02 & 0 & 9.38 & 1.03 & 71.62 & 6378.09 & 105.02 & 187.08 \\
\hline Saline-alkali land & 10.25 & 2.06 & 2.44 & 0.27 & 100.01 & 20.15 & 0.03 & 4449.31 & 135.21 \\
\hline Area transferred out, 2010 & 397.34 & 865.27 & 30.2 & 415.51 & 200.30 & 254.13 & 230.35 & 172.90 & \\
\hline
\end{tabular}

In recent years, human activities in the Manas River Basin have intensified. With the development of society and the economy and the increasing population, a large amount of farmland has been cultivated and the area of construction land has expanded. In the five study periods during 1976-2015, the oasis area was $3480.2,4894.9 \mathrm{~km}^{2}, 5817.2 \mathrm{~km}^{2}, 6704.7 \mathrm{~km}^{2}$ and $7982 \mathrm{~km}^{2}$, respectively, showing an obvious increase. The increase rate during 1976-1990 was the most obvious, with a growth rate of $40.6 \%$, the growth rate for $1990-2000$ was $18.8 \%$, for $2000-2010$ was $15.3 \%$ and for $2010-2015$ was $19.1 \%$ - the growth rate of oasis area in the last 40 years was $129.4 \%$. With the disturbance of human activities and the change in natural factors, land degradation has occurred to differing degrees in the Manas River Basin. The land-use type transfer matrix analysis showed that the desertification degree in the study area had decreased progressively in recent years. During 1976-1990, the desertification area was $448.5 \mathrm{~km}^{2}$, and the area of human desertification was $318.8 \mathrm{~km}^{2}$; the corresponding values were $260.44 \mathrm{~km}^{2}$ and $102.10 \mathrm{~km}^{2}$ in 1990-2000; $408.34 \mathrm{~km}^{2}$ and $149.10 \mathrm{~km}^{2}$ in 2000-2010; and $217.92 \mathrm{~km}^{2}$ and $106.60 \mathrm{~km}^{2}$ in $2010-2015$.
The change of land use in the Manas River Basin was very significant, especially for Manas Lake with its water area shrinking year by year, and finally drying up and becoming saline-alkali land. Spatially, the area of land-use change continued to expand along with Manas, Shihezi and Shawan and extending to the northern desert. The water demand in the region is increasing, which has led to a large amount of atrophy of wetland and water, and the agricultural water use in the basin is greater than that of ecological water. Thus, the transformation type has gradually changed from two-way to one-way transformation. The change of landscape pattern in the first 10 years was greater than in the last 10 years. The main reason is that the Xinjiang Construction Corps used a large amount of grassland and unused land in the 1990s to carry out large-scale land development and building construction.

\subsection{Analysis of landscape pattern changes in the Manas River Basin}

As the intensity of human activities increases, land use/cover types change frequently ${ }^{[20]}$. The directional selection of human beings results in the degradation or disappearance of some types of landscape (e.g., forest land and grassland). Some landscape types 
expand, and the distribution tends to be connected (e.g., farmland). The natural landscape is divided into different types of landscape patches, with mosaic distribution and fragmentation degrees increasing ${ }^{[21]}$. The land-use data of the Manas River Basin in the five periods of 1976-2015 were analyzed. The change in the number of patches of different land-use types could reflect the increasing trend of fragmentation of landscape types.

The patch area of forestland decreased during 1976-2015, and the number of patches generally increased. The increasing trend of the number of patches from 1976-1990 was significant, from 167 to 364 . It can be seen that the forest land was occupied more seriously during this period. On the one hand, the increase in the number of patches indicates that some sparse and small forest land deforestation disappeared; on the other hand, the large area of forest land was divided and encroached, and the maximum patch area of the forest land can be more intuitively explained. From 1976-2015, the largest patch area of forest land was $151.68 \mathrm{~km}^{2}$, $140.72 \mathrm{~km}^{2}, 103.08 \mathrm{~km}^{2}, 77.18 \mathrm{~km}^{2}$ and $71.29 \mathrm{~km}^{2}$, respectively. Large areas of forest land were deforested during 1990-2010, and the maximum patch area decreased significantly.

The changing trend of grassland landscape type was more complex, with the number of patches increasing, decreasing and increasing during 1976-1990, 1990-2000 and 2000-2015, respectively. The overall reduction in grassland area was not significant, mainly because the grassland area was mainly concentrated in middle and high mountain areas, which experienced a low degree of human activity.

Human activities resulted in the increasing number of patches of water area, with obvious decreases in the area of patches during 1976-2000 and increases during 2000-2015. The main reason is the permanent snow and glacier ablation, and the most obvious snow and glacier ablation is the decrease of the depth of snow, not
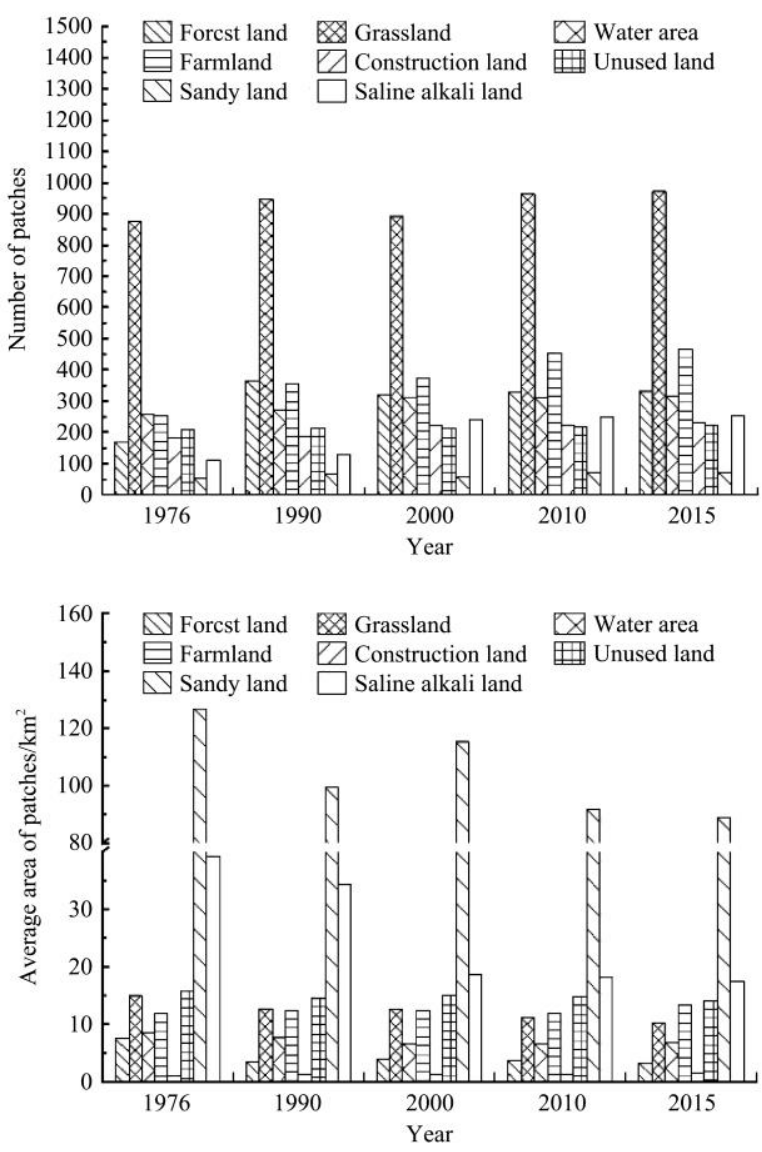

the change of area, at a certain time. The decreasing trend of water area in the period was not large, but the water area of the basin is needed to build the reservoir for flood control and flood control, which caused the measured water area to increase annually after 2000. However, the maximum patch area did not change after 2000, indirectly showing that artificial water storage had a great impact on the composition of the water area.

As the most intuitive embodiment of human activities, the farmland area increased year by year from 1976-2015. The patch area continued to expand, and the average patch area had a trend of "increase-decrease-increase", indicating that the increase of farmland area was mainly based on small area land reclamation at different spatial scales. From 1976-1990, the number of farmland patches increased most obviously, with the largest patch area during 2010-2015, indicating that farmland was developing in a centralized and integrated development, with the land reclamation mode strongly influenced by the Xinjiang Production and Construction Corps.

The number of construction land patches increased year by year after 1976, with the fastest growth rate from 1990-2000. The patch area increased obviously by $45.68 \mathrm{~km}^{2}$ during 1976-1990, by $54.94 \mathrm{~km}^{2}$ during 2010-2015, and the maximum patch area was $45.13 \mathrm{~km}^{2}$ in 2015 , indicating that construction land expanded rapidly and the combination of urban and rural areas was more complete.

The total patch area of unused land, sandy land and saline-alkali land accounted for $41.79 \%$ of the total basin area, and patch number increased year by year, which was significantly affected by human activities. Over the past 40 years, the area of unused land, sandy land and saline-alkali land did not change much, showing a general trend of reduction, and the largest patch area increased year by year (Figure 4).
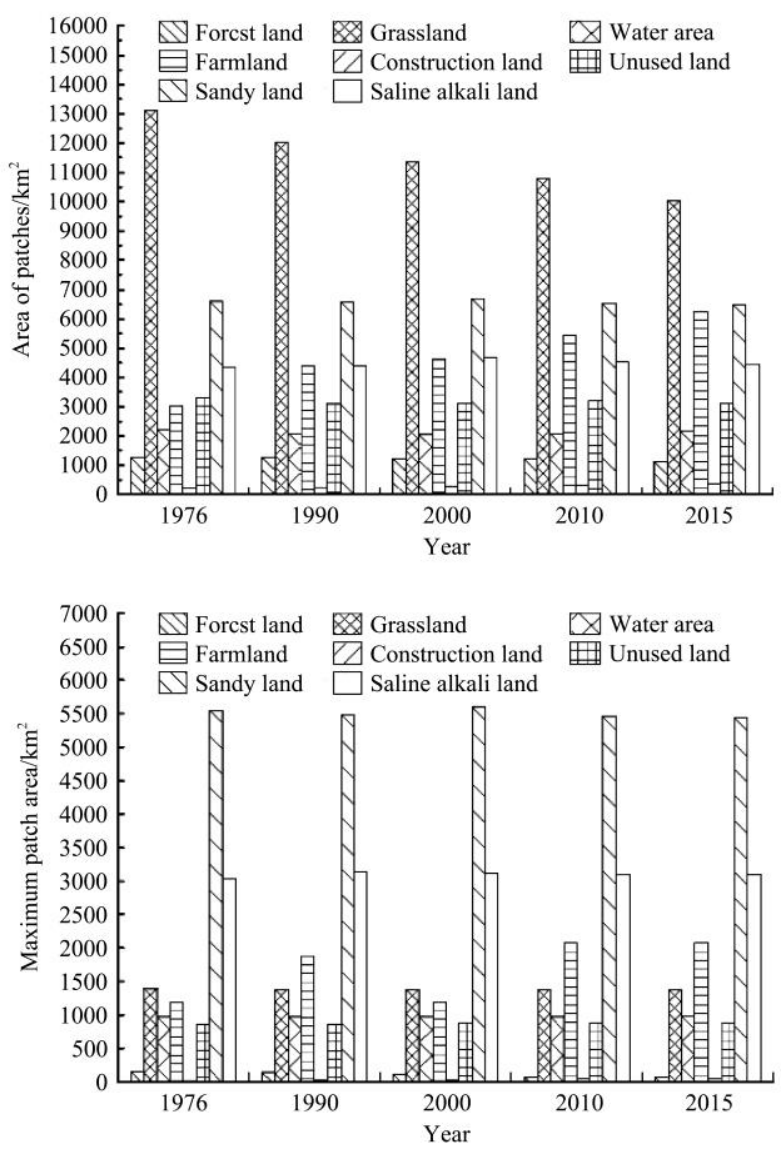

Figure 4 General characteristics of landscape in the Manas River Basin during 1976-2015 
The diversity index measures the diversity and complexity of land-use types. The diversity index directly reflects the change of type of land use and the proportion of various types (Figure 5).

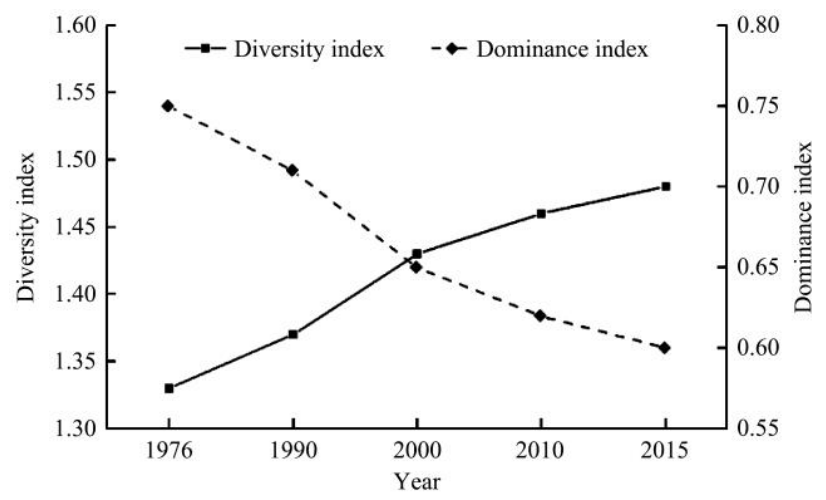

Figure 5 Diversity index analysis of the Manas River Basin during 1976-2015

From 1976-2015, the diversity of the Manas River Basin increased gradually and the dominance index decreased gradually. The folding line was close to symmetry (Figure 6). The variation trends of the diversity and the dominance indexes showed that the landscape heterogeneity of the whole basin gradually increased, and the different types of land were in disequilibrium in the landscape. In the area of increasing landscape heterogeneity, the overall landscape pattern is increasingly controlled by the majority of the patches. The number of land-use types in the five stages of the basin did not change, indicating that the proportion of the total area of each type was gradually reduced. The landscape diversity index of the basin rose from 1.7190 in 1976 to 1.8080 in 2015 . Under the given richness, the maximum possible diversity index of the landscape was 2.0794, indicating that under the established classification system of land use, the diversity was high, and the proportion of landscape types decreased year by year, and the landscape changed. The degree and complexity of landscape heterogeneity increased. The landscape dominance index of the Manas River Basin declined from 0.3596 in 1976 to 0.2714 in 2015. This shows that the proportion of differences between the dominant landscape types and other landscape types was narrowing, and the landscape structure tended to be uniform. The dominant degree of grassland and sandy land in the Manas River Basin decreased year by year, consistent with the conclusion that the area of grassland and sandy land decreased at the same level.

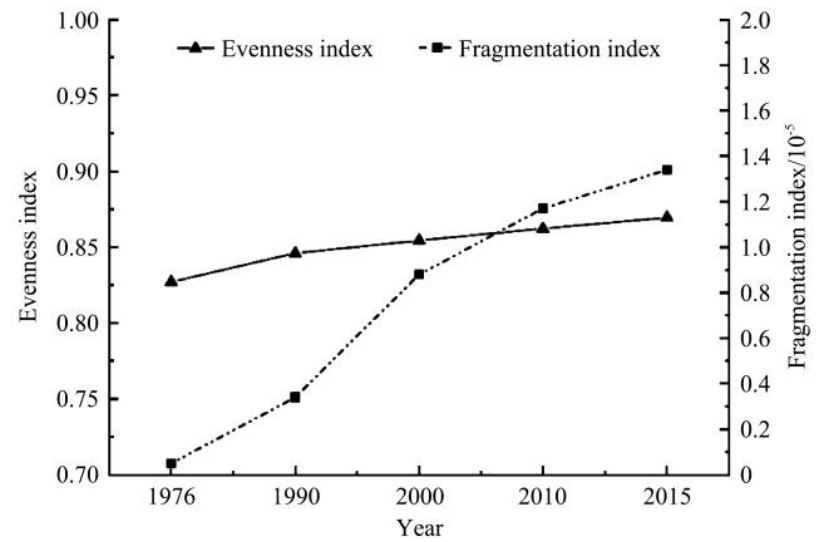

Figure 6 Analysis of fragmentation index and evenness index of the Manas River Basin during 1976-2015

The initial fragmentation index was small, indicating a low degree of landscape fragmentation, and that the watershed landscape as a whole was relatively complete. During 1990-2000, the landscape fragmentation index showed an obvious increasing trend, indicating that with the increase of social and economic development and population, the land-use types with larger patches were divided into many smaller patches. Especially in the southern margin of the Gurbantungut Desert near the oasis, a large amount of cultivated land was reclaimed, resulting in increased landscape fragmentation. The evenness index reflects the evenness of the distribution of patch types in the landscape and was 0.8271 in 1976, 0.8460 in 1990, 0.8544 in 2000, 0.8622 in 2010 and 0.8695 in 2015 . Generally speaking, the area of each patch type in the basin landscape tended to gradually homogenize, and the fragmentation index increased year by year.

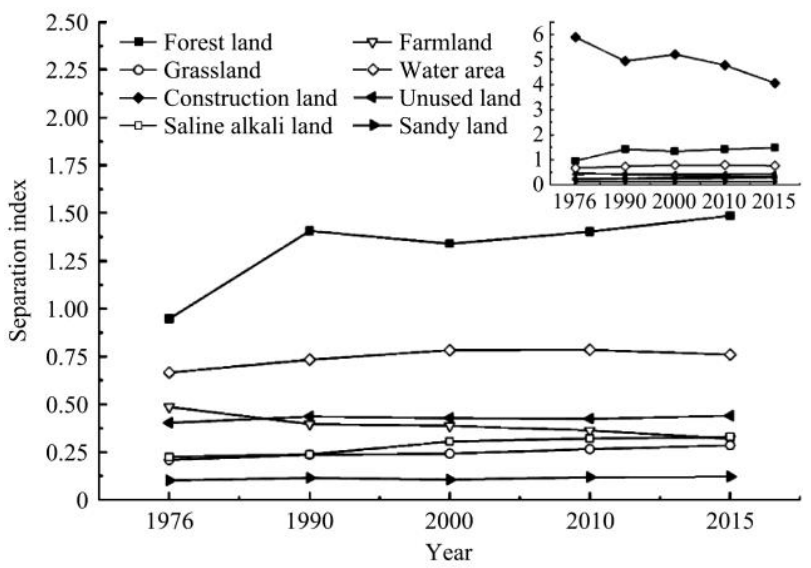

Figure 7 Analysis of fragmentation index and evenness index of the Manas River Basin during 1976-2015

The landscape separation index refers to the degree of dispersion of the distribution of the same landscape type. The landscape segregation index can show the influence of patch density and area ratio on the degree of landscape segregation. It is very important to analyze the formation mechanism of landscape pattern and to understand the distribution characteristics of landscape pattern ${ }^{[22]}$. The landscape-type separation index calculation in the Manas River Basin showed that the degree of separation of construction land was the largest, followed by forestland, water area, unused land, farmland, saline-alkali land, grassland and finally by sandy land. The landscape-type separation index calculation accords with the actual situation. For many years, reclaimed basin and implementing of high-efficiency water-saving irrigation in the basin have formed a good layout of people entering and retreating sand. The high connectivity and low degree of separation of sandy land in the basin were the key limiting factors for oasis development. The calculation of patch number and patch area of landscape type showed that the average patch area of construction land was the lowest among landscape types, and construction land was distributed in the plain area of the middle of the basin, with a small area index and a large number of patches.

The time-scale analysis of landscape-type separation trend showed that in the five land-use types during 1976-2015, only the landscape separation of saline-alkali land and grassland continued to increase. The grassland landscape separation rose from 0.2083 in 1976 to 0.2857 in 2015 , with a growth rate of $37.16 \%$. The landscape separation degree of saline-alkali land increased from 0.2242 in 1976 to 0.3284 in 2015 , with a growth rate of $46.78 \%$. During 1989-2000, the separation degree of saline-alkali land increased significantly, and the separation degree of farmland 
decreased. This is because, after 1998, drip irrigation under mulch was popularized in the basin, and drip irrigation pipes and drip-pipe belts replaced flood and ditch irrigation and agricultural trunk and branch channels were excavated. Drip irrigation under mulch allowed some of the secondarily-saline abandoned farmland caused by traditional flooding and furrow irrigation to be restored to cultivation, and part of the agricultural canals and drainage canals were reorganized into arable land, which improved the utilization rate of agricultural land and changed the pattern of arable land. During 1976-2015, the degree of separation of farmland landscape types decreased from 0.4861 to 0.3185 , with a growth rate of $-52.62 \%$. The farmland was distributed along with the river and canal system in 1976, with multiple distribution centers and a high degree of separation (Figure 2). There was a good linear relationship between canal system length and farmland area during the period of flooding and furrow irrigation, and this internal relationship was the factor directly driving the change in farmland pattern $^{[23]}$. With the expansion of farmland and the popularization of water-saving measures in the basin, the farmland area gradually increased and became more intensive, and the former scattered farmland gradually became one piece, with a lower degree of separation; the other landscape types, including construction land, forest land, water area, unused land and sandy land, changed more smoothly. The separation degree of construction land was the largest, with a decreasing trend in general from 5.8953 in 1976 to 4.0616 in 2015, and a growth rate of $-45.15 \%$. The decrease of the separation degree between construction land and farmland landscape type indicates that the urbanization level of the basin increased, and human activities gradually dominated the changing trend of land-use types. Similar to the previous land-use types, the landscape types of forest land, water area, unused land and sandy land had a higher degree of separation, and the landscape types had a smaller area and were seriously affected by human activities.

\subsection{Discussion}

From the upper reaches of the valley to the desert area, the reduction rate of the number and density of patches in the mountain area was $2.2 \%$, and the increase rate of the evenness and diversity index was about $0.6 \%$, indicating that the landscape type of the mountain area was more diverse. The interference of humans in the mountain area was relatively small, and the main force causing changes in landscape pattern was that the grassland and some unused land in the front of the mountain transition zone were developed into farmland and construction land, and the artificially gradually transferred to the alluvial fan.

In the oasis plain area, the number, density and separation degree of the farmland have been reduced, the intensification degree of farmland increased and this, combined with the scale of production, greatly influenced the landscape pattern changes in the oasis area and the whole basin. As the core of the whole river basin, the land-use mode of the oasis area is based on the economic benefit, and the forest land and grassland have been occupied to a large scale by other land uses, especially farmland and construction land. Thus, the forest land and grassland have been divided into smaller patches, with their distribution becoming increasingly scattered. Construction land showed a continuous trend of agglomeration and expansion, with its dominance constantly increasing, and it has become an important type of landscape pattern in the oasis region. The pattern of unused land changed greatly, and its dominance declined as it was occupied and divided by other land uses, and the patches became more fragmented with connectivity significantly reduced. During 1976-2015, farmland increased in the Manas River Basin and its connectivity and cohesion increased. The increase in the irrigation area aggravated the consumption of water resources, and the artificial reservoir canal replaced the natural river so that the river was blocked and its spatial connectivity reduced. Within the oasis, the complexity of patch shape decreased with the increase in agricultural and urbanization levels and tended to simplify and become stable. In general, the oasis area is the ecological benefit area in the basin, and it is also the most frequent area of human activity and has the greatest degree of the artificial landscape. The landscape pattern was influenced by various land-use methods, thus achieving a restrictive balance. From the view of the landscape, the shape of the desert landscape was increasingly complex, the irregularity and fragmentation increased, and the distribution of patches was more even due to human activities and the development of high-intensity land use. To meet the needs of life and production, human beings began to seek land in the oasis desert transitional zone, especially on the edge of the desert, which is increasingly affected by human activities, and combined with the shortage of water resources has made the ecology more fragile.

Overall, in the past 40 years, the landscape pattern of the Manas River Basin showed the characteristics of diversification, complexity and fragmentation. The change of landscape pattern and its ecological effects indicate that the effects of land use and development activities should be evaluated, regional ecological construction and ecological security control should be strengthened, and the impact of human activities on landscape evolution should be directed in a more positive fashion to realize the sustainability and stability of watershed development.

Human activities not only caused changes in the landscape pattern in the basin but also affected ecological processes, with different ecological effects ${ }^{[24]}$. In the northwest arid area, in order to make full use of limited water resources, artificial channels are usually used instead of natural rivers and reservoirs to actively regulate water resources. This improves the efficiency of water resource utilization, influences the role of water ecological factors in the development of the regional ecological environment and influences the change of landscape pattern in the region. Through the development of water resources, the spatial and temporal distribution of water resources was changed, which had an important impact on the change of landscape pattern in this arid watershed. The land use and landscape patterns of the Manas River Basin had different characteristics in the mountain, oasis and desert areas, and the hydrology ecological effect was remarkable, with the hydrological cycle and the allocation of water resources obviously changed. The spatial distribution and change of water resources played leading roles in the distribution of various landscapes in the basin. Landscape response to drivers of change is more visible and noticeable in deltas and floodplains than upstream $^{[25]}$. The river corridor not only has the function of transmitting energy and nutrients but is also the carrier and source of oasis biological flow. The change in desert oasis landscapes in arid areas is more reflected by the change of biological flow caused by changes in the river corridor ${ }^{[26]}$.

The development of artificial oases in the basin has changed the composition of natural ecosystems ${ }^{[27]}$. There are two closely linked landscape patterns in the region: one is near the water source and the upper reaches of the river basin, and is a farmland 
landscape with advanced farming, intensive and irrigation systems; the other is far from the water source and in the middle and lower reaches of the river basin, with the continuous improvement of the water resources being attacked and the natural ecosystem. The system is constantly destroyed, and the landscape develops from highly fragmented natural vegetation to the highly dominant desert landscape. With the interference of strong human activities in reclaiming oases and increasing the farmland area, the change in landscape pattern is mainly characterized by unstable fluctuations that exceed the ecological safety threshold, and result in a series of environmental degradations.

\section{Conclusions}

(1) Analysis of the change process of land use in the Manas River Basin during the period 1976-2015 showed a significant land-use change, with dynamic changes in land use, the transformation type gradually proceeding from two-way to one-way transformation and transformation occurring frequently. The main feature was that unused land reduced greatly and the farmland significantly increased.

(2) The diversity of landscape patterns in the basin generally increased, but the dominance index decreased. The landscape structure tended to be uniform through the increase of the evenness index year by year, indicating that differences between the dominant landscape types and other landscape types were decreasing, and the degree of landscape fragmentation was enhanced. At the same time, the number of patches increased and the average area of patches decreased, indicating that the degree of landscape fragmentation increased.

(3) In the past 40 years, the landscape pattern of the Manas River Basin showed characteristics of diversification, complexity and fragmentation. The changes in landscape pattern and its ecological effects indicated that human activities strongly affected the landscape pattern. The rapid developments of the social economy and the increasing degree of human land use have led to enhanced fragmentation of the landscape. The landscape pattern of the basin depends on the coordinated development of the sustainable utilization of the land and water resources and orderly human activities. Therefore, the rational use of water resources and optimization of the exploitation and utilization of land resources are key elements to maintain the stability of the landscape structure and function of this basin.

\section{Acknowledgements}

This work was financially supported by the National Natural Science Foundation of China (U1803244); Major scientific and technological projects of Xinjiang Production and Construction Corps (2017AA002); Science and Technology Research Project of Xinjiang Production and Construction Corps (2018AB027); Scientific Research Program of Shihezi University (KX00860105, KX008201, CXRC201801); Innovation and Development Support Program of Key Industries in Southern Xinjiang (2020DB001); Key Research and Development Program of National "13th Five-Year Plan” (2016YFC0501402).

\section{[References]}

[1] Nendel C, Hu Y F, Lakes T. Land-use change and land degradation on the Mongolian Plateau from 1975 to 2015--A case study from Xilingol, China. Land Degradation \& Development, 2018; 29(6): 1595-1606.

[2] Kenny D C. Modeling of natural and social capital on farms: Toward useable integration. Ecological Modelling, 2017; 356: 1-13.

[3] Lizaga I, Quijano L, Palazon L, Gaspar L, Navas A. Enhancing connectivity index to assess the effects of land use changes in a Mediterranean catchment. Land Degradation \& Development, 2018; 29(3): 663-675.

[4] Luyssaert S, Jammet M, Stoy P C, Estel S, Pongratz J, Ceschia E, et al. Land management and land-cover change have impacts of similar magnitude on surface temperature. Nature Climate Change, 2014; 4(5): 389-393.

[5] Vranken I, Baudry J, Aubinet M, Visser M, Bogaert J. A review on the use of entropy in landscape ecology: heterogeneity, unpredictability, scale dependence and their links with thermodynamics. Landscape Ecology, 2015; 30(1): 51-65.

[6] Prevedello J A, Gotelli N J, Metzger J P. A stochastic model for landscape patterns of biodiversity. Ecological Monographs, 2016; 86(4): 462-479.

[7] Wang L, Manzoni S, Ravi S, Riverosiregui D A, Caylor K K. Dynamic interactions of ecohydrological and biogeochemical processes in water-limited systems. Ecosphere, 2016; 6(8): 1-27.

[8] Fu Q, Li B, Hou Y, Bi X, Zhang X. Effects of land use and climate change on ecosystem services in Central Asia's arid regions: a case study in Altay Prefecture, China. Science of the Total Environment, 2017; 607: 633-646.

[9] Haverd V, Smith B, Nieradzik L, Briggs P R, Woodgate W, Trudinger C M, et al. A new version of the CABLE land surface model, incorporating land-use change, woody vegetation demography and a novel optimisation-based approach to plant coordination of photosynthesis. Geosci. Model Dev., 2018; 11: 2995-3026.

[10] Elkawy O R, Rod J K, Ismail H A, Suliman A S. Land use and land cover change detection in the western Nile delta of Egypt using remote sensing data. Applied Geography, 2011; 31(2): 483-494.

[11] Tsegaye D, Moe S R, Vedeld P, Aynekulu E. Land-use/cover dynamics in Northern Afar rangelands, Ethiopia. Agriculture, ecosystems \& environment, 2010; 139(1-2): 174-180.

[12] Lira P K, Tambosi L R, Ewers R M, Metzger J P. Land-use and land-cover change in Atlantic Forest landscapes. Forest Ecology and Management, 2012; 278: 80-89.

[13] Liu B, He X L. Response of groundwater to the process of reservoirs group regulation and storage in Manas River Basin in Xinjiang. Int $\mathrm{J}$ Agric \& Biol Eng, 2020; 13(1): 224-233.

[14] Li P F, Yang G, He X L, Li F D, Yan K, Wang Z L. Effects of drip irrigation on components of water cycle in arid inland areas: A case study of Manas River Basin in northwestern China. Int J Agric \& Biol Eng, 2019; 12(1): 132-138.

[15] Yang G, Chen D, He X L, Long A H, Yang M J, Li X L. Land use change characteristics affected by water saving practices in Manas River Basin, China using Landsat satellite images. Int J Agric \& Biol Eng, 2017; 10(6): 123-133.

[16] Yang G, He X L, Li X L, Long A H, Xue L Q. Transformation of surface water and groundwater and water balance in the agricultural irrigation area of the Manas River Basin, China. Int J Agric \& Biol Eng, 2017; 10(4): 107-118.

[17] Li X L, He X L, Yang G, Zhao L, Chen S, Wang C, et al. Study of groundwater using visual MODFLOW in the Manas River Basin, China. Water Policy, 2016; 18(5): 1139-1154.

[18] Yang X, Zheng X Q, Chen R. A land use change model: Integrating landscape pattern indexes and Markov-CA. Ecological Modelling, 2014; 283(7): 1-7.

[19] Howey M C L, Burg M B. Assessing the state of archaeological GIS research: Unbinding analyses of past landscapes. Journal of Archaeological Science, 2017; 84: 1-9.

[20] Jew E K K, Dougill A J, Sallu S M. Tobacco cultivation as a driver of land use change and degradation in the Miombo woodlands of southwest Tanzania. Land Degradation \& Development, 2017; 28(8): 2636-2645.

[21] Jiang Y F, Wang W, Zhang T, Pei H, Liang C Z, Wang L X. Research on the land use and landscape type changes of Ewenke Autonomous County. Journal of Arid Land Resources \& Environment, 2008; 22(2): 122-127. (in Chinese)

[22] Lausch A, Blaschke T, Haase D, Herzog F, Syrbe R U, Tischendorf L, et al. Understanding and quantifying landscape structure - A review on relevant process characteristics, data models and landscape metrics. Ecological Modelling, 2015; 295(Supp): 31-41. 
[23] Li J J, Luo G P, Ding J L, Xu W Q, Zheng S L. Effect of progress in artificial irrigation and drainage technology on the change of cultivated land pattern in the past 50 years in Manasi River watershed. Journal of Natural Resources, 2016; 31(4): 570-582. (in Chinese)

[24] Jaramillo F, Destouni G. Comment on "Planetary boundaries: Guiding human development on a changing planet". Science, 2015; 348(6240): 1217. doi: 10.1126/science.aaa9629.

[25] Abate M, Nyssen J, Moges M M, Enku T, Zimale F A, Tilahun S A, et al. Long-term landscape changes in the Lake Tana basin as evidenced by delta development and floodplain aggradation in Ethiopia. Land Degradation
\& Development, 2017; 28(6): 1820-1830.

[26] Herguido E, Lavado Contador J F, Gómez Gutiérrez A, Schnabel S Modeling tree loss versus tree recruitment processes in SW Iberian rangelands as influenced by topography and land use and management. Land Degradation \& Development, 2017; 28(5): 1652-1664.

[27] Smiraglia D, Ceccarelli T, Bajocco S, Perini L, Salvati L. Unraveling landscape complexity: land use/land cover changes and landscape pattern dynamics (1954-2008) in contrasting Peri-Urban and Agro-Forest Regions of Northern Italy. Environmental Management, 2015; 56(4): 916-932. 